\title{
EFFECT OF ENGLISH PROFICIENCY ON SOCIAL CAPITAL AND ACADEMIC ACHIEVEMENT AMONG ECONOMIC STUDENTS
}

\author{
Muhammad Sodbir Hamzah \\ Universiti Utara Malaysia \\ Hussin Abdullah* \\ Universiti Utara Malaysia \\ Mazida Ahmad \\ Universiti Utara Malaysia
}

\begin{abstract}
The use of English language becomes increasingly important, either in educational sector or working sector. The role of social capital should be taken into consideration in helping the students to achieve their academic success. Previous findings indicated that students with limited use of English faced problems in advance subjects. Thus, this study examines the effect of English language proficiency towards social capital and academic achievement. This study employed the survey research design and the sample comprised of 81 undergraduate students enrolled in Economics courses from year two and three in Universiti Utara Malaysia (UUM). The instruments were adapted based on the constructs in the structural model developed. The data has been analysed using Structural Equation Modelling to enable simultaneous analysis of all the constructs and estimate the magnitude of the direct and indirect effects between the constructs. The findings show that there is a significant direct effect of English Language Proficiency (ELP) towards Academic Achievements (AA) and Social Capital Outside Family (SCOF), and from social capital outside family towards academic achievements. The mediating effect of social capital outside family towards English Language Proficiency (ELP) and Academic Achievement (AA) among economics students in UUM was significant. The findings suggest for more activities geared towards increasing students' English language proficiency to help them to increase their academic achievements.
\end{abstract}

Keywords: English Language Proficiency; Social Capital; Academic Achievement.

\section{INTRODUCTION}

The use of English language as medium of communication becomes increasingly important. One of the objectives in government transformation program (GTP) is to provide a quality education for all. Hence, a special focus has been put towards English language proficiency

* Corresponding author: School of Economics, Finance and Banking, College of Business, Economics Building, Universiti Utara Malaysia, 06010 Sintok, Kedah, Malaysia. Tel: +604-9286862, Fax: +604-9283502. Email: hussin2141@uum.edu.my 
in preparing the students for challenges and opening up the students' possibilities in the future (GTP, 2011) as it is an important factor for students to further their study and for employment purposes. Bachman (1990) defines language proficiency as the language ability or ability in language use while Oller (1983) defines language proficiency as an ability of several distinct but related constructs. An individual with inability or limited language proficiency will face difficulties in finding employment opportunities (Yasin, Shaupil, Muhktar, Ghani \& Rashid, 2010; Jalaluddin, Mat Awal \& Abu Bakar, 2009) and eventually will become a hindrance towards the growth of Malaysia because English language proficiency is now assumed to be one of the determinants for Malaysia growth (Hj Sarudin, Zubairi, Nordi, \& Omar, 2008). In tertiary education, language proficiency becomes more important due to the lectures, tutorials and references that are mostly in English. English language is also offered in the universities to help enhance students' language proficiency.

By having a proficiency in English language, it helps students to communicate and involve in many activities involving non-Malay language speaker in Malaysia. As speaking or oral communication skill was ranked as the most important transferable skill ahead of other skill such as reading, writing and listening (Kwok, 2004), it is useful in helping the students to widen their structures of friends with different resources and increase their social network. Coleman (1988) defined social capital by its function and it is productive just like other physical capital. It is useful in the achievement of certain ends and its absent would not be possible. Drennan \& Rohde (2002) indicate that English language is a proxy for something else such as learning style, and in this case it is to achieve excellent academic achievement.

A research by Drennan \& Rohde (2002), studied the effect of English language proficiency towards academic achievement among accounting students in University of Queensland, Australia. The findings showed that students with limited use of English faced problems in advance subjects and not in the introductory level subjects. The reason is because advance subjects would require students to involve in problem solving activities where interpretive skill would require. So, do economics students in UUM produce the same result or differ?

Thus, this research is done to study the effects of English language proficiency towards students' academic achievement among undergraduate economics students in UUM and to examine the mediating effect of social capital outside family. For completeness, the overview of social capital and academic achievement will be discussed in details in section two. The third section describes the method used in the implementation of this study andthe last section describes the findings and conclusion of this study.

\section{SOCIAL CAPITAL}

Social capital has becomes increasingly important, as equally important as human capital. Bourdieu (1986) defined social capital as accumulation of resources within a durable network having institutionalized relationships of mutual acquaintance and recognition. Whereas Adler and Kwon (2002) defined social capital as the goodwill that is engendered by the fabric of social relations and that can be mobilized to facilitate action. Coleman (1988) defined social capital by its functions and stated that it is not a single entity but a variety of various entities 
having two elements in common, having some aspect of social structure and helps to facilitate certain action within the structure.

Despite having fundamental differences such as between Bourdieu (1986) and Coleman (1988), these two definitions possess the same criteria, social network and mutual agreement and can be used to achieve a certain objective and this social network and mutual agreement can be translated into economic capital. (Dika \& Singh, 2002). For the purpose of this study, theory by Coleman (1988) will be used. According to Coleman (1988), social capital can be utilized in the creation of human capital. Social capital can then be divided into two, within family and outside family. This study concentrates on the social capital outside family due to the students' environmental factor.

\subsection{Social capital outside family}

Coleman (1988) stated that indicator outside family is residual stability, i.e. it helps to provide closure in child relationship with adults. Even though the explanation provided by Coleman (1988) was not comprehensive, it was complemented by Putnam (2001), who stressed more on indicators from outside family to increase social capital. He has underlined four major indicators to increase social capital outside family, political participation, organizational membership, religious participation and informal visiting and involvement. Based on these two views, the basis or fundamental behind the indicators or social capital are trust and reciprocity. It relates how one should accept and be accepted by the family and community, and how these indicators are used to help him to improve his social capital. This relates to the earlier defined objective of social capital which is to have a useful social network to achieve a certain objective.

Crosnoe (2004) in his research using multilevel modelling on national representative data of 11,927 respondents in America revealed that students' academic achievements was inversely correlated with a lack of family-based social capital and directly related to school-based social capital. This means that students' academic achievements would depend on within family social capital. However, if the social capital within family is low, students would eventually find another way to replace that; i.e. by having a higher social capital outside family, which in his study, Crosnoe focused on the social capital at school.

In looking at the effect of social capital, Adler and Kwon (2002) have listed five areas in which social capital will have the influence on. However, the listed influences are more towards the organization and working environment, but also useful towards educational environment. The influences are:

i. Social capital influences career success and executive compensation.

ii. Social capital helps workers find jobs and create a richer pool of recruits for firms.

iii. Social capital facilitates inter unit resource exchange and product innovation, the creation of intellectual capital and cross cultural team effectiveness.

iv. Social capital reduces turnover rates and organizational dissolution rates, and it facilitates entrepreneurship and the formation of the start-up companies.

v. Social capital strengthens supplier relations, regional production networks and inter-firm learning. 
Stephen, Welman and Jordaan (2004) indicated that academic success would depend on many factors such as English as the second language as well as social and environmental effect that have direct influence on level of persistence and motivation. The better the social or the environment, the better it is the chances of academic success. But, in his findings, he indicated family as one of the indicator contributing to English language proficiency.

Croll (2004) conducted a study to study the role of the family towards education. The empirical data was based on the British Household Survey, which is a large sale and on-going interview survey in which the same people have been interviewed annually since 1991 . One of the particular features of the survey was that all members of a household were interviewed including the young aged from 11 to 16 . The context of the study is the inter-generational transmission of social structure and social change in the United Kingdom and elsewhere in the develop world. The objective of the study was to show the importance of families, who matters subjectively to young people and important to their educational outcomes. Family social capital such as what the parents do in term of communication and other activities, both within and outside the family, direct parental mentoring, parent-child communication and parental involvement in wider social network are taken into consideration. The results showed that social capital within family is more self-contained and greater effect comes from social capital outside family as outlined by Coleman and Putnam.

Crosnoe (2004) also look at the interplay between families and schools. In his research, the data was taken from National Longitudinal Study of Adolescence Health, which is an on-going study of adolescence that was in grade $7-12$ in 1994 consisting of 11,927 respondents. The sample schools were selected from a list of American high schools based on region, urbanity, school type, racial composition and size. The objective was to see which of the source of social capital of the adolescence, families or schools help to shape their life development. The results showed that those who have low social capital at home, or have emotionally distant relationship with parents were associated with declining academic achievement. But at the same time, the decline is being replaced with high social capital at schools help to improve their academic achievement. Also, the findings showed that adolescence with high social capital at home benefited more from social capital at school.

The literature reviews on social capital indicate that there exist a relationship between English language proficiency and social capital outside family and between social capital outside family and academic achievement, and social capital outside family can be examined as a mediator to increase academic achievement.

\section{ACADEMIC ACHIEVEMENT}

Johnson (1988) and Naderi et al. (2009) used Grade Point Average (GPA) as the indicator to measure academic achievements in their research. Johnson (1988) chose 196 undergraduate students in University of Wisconsin-Green Bay (UWGB) as respondents to test the effect of English proficiency towards academic achievements which measured through TOEFL result and GPA. Her findings indicate that when English language proficiency is relatively low, academic achievement which translated as GPA can be predicted. The English language 
proficiency is measured through the result for TOEFL used as university entry requirements. In other words, the higher the English language proficiency, the better the chances for the students to have higher academic achievement, or CGPA. The finding is a bit different compared to Drennan and Rohde (2002) who stated that English language proficiency only effect advance subjects that require problem solving and interpretive skills as explained earlier. Thang, Ting and Jaafar (2011) also stated that Malaysian students have already acknowledge and understand the importance of English language towards their future and motivated by factors such as desire to get good grades and opportunities to further their studies.

So, based on these two studies, it is applicable to use CGPA as the indicator to measure students' academic performance and it also shows the positive relationship that English language proficiency has towards academic achievements.

This paper discusses direct effects of English language proficiency towards students' academic achievement among undergraduate Economics students in UUM and to examine the mediating effect of social capital outside family. In order to assess empirically the effects, the following hypotheses have been formulated.

$\mathrm{H}_{1}$ : Students' English language proficiency contributes a positive effect towards the students' academic achievements.

$\mathrm{H}_{2}$ : Students' English language proficiency contributes a positive effect towards the students' social capital outside family.

$\mathrm{H}_{3}$ : Students' social capital outside family provides a positive effect towards the students' academic achievements.

$\mathrm{H}_{4}$ : The impact of English Language Proficiency on students' academic achievement is mediated by the students' social capital outside family.

\section{METHODOLOGY}

\subsection{Procedure and sample}

The research procedure is depicted in Figure 1. In theoretical phase, reviews of the literature are carried to gather the related information regarding the English language proficiency among the students and its relationship with academic achievement are being studied.

Once the information has been gathered, a critical analysis was done on existing frameworks, which lead to the formation of conceptual model of this study. Then, the hypothesized model based on the conceptual model was produced to construct the instruments for the study. From that, the instruments were updated. The pilot study was carried out in March 2012. From the study, the Cronbach Alpha value for the instrument was 0.769 for social capital outside family, which is reliable because it is greater than the threshold value 0.6 (Nunnally, 1978). The sample of the study consisted of Economic undergraduates in Semester 2 at UUM. The reason for selecting the sample is because these students will have a better understanding of the economics courses in UUM as well as having completed their English for Communication II, which is compulsory for all Economics undergraduates in UUM. At the end of the semester, 
100 questionnaires have been distributed to the students and 81 questionnaires were returned, representing an acceptable response rate. Then the data were gathered and analysed using descriptive analysis and PLS by utilizing SPSS version 18 and SmartPLS 2.0 to analyse the model. In this study, PLS based is employed, because PLS makes fewer demands regarding the sample size and can be used for theory confirmation or theory development, which include using to develop prepositions by exploring the relationship between variables (Chin, 1998). Since the model in this study is conceptualized based on literature review, then PLS is applicable.

Figure 1: Research Procedures

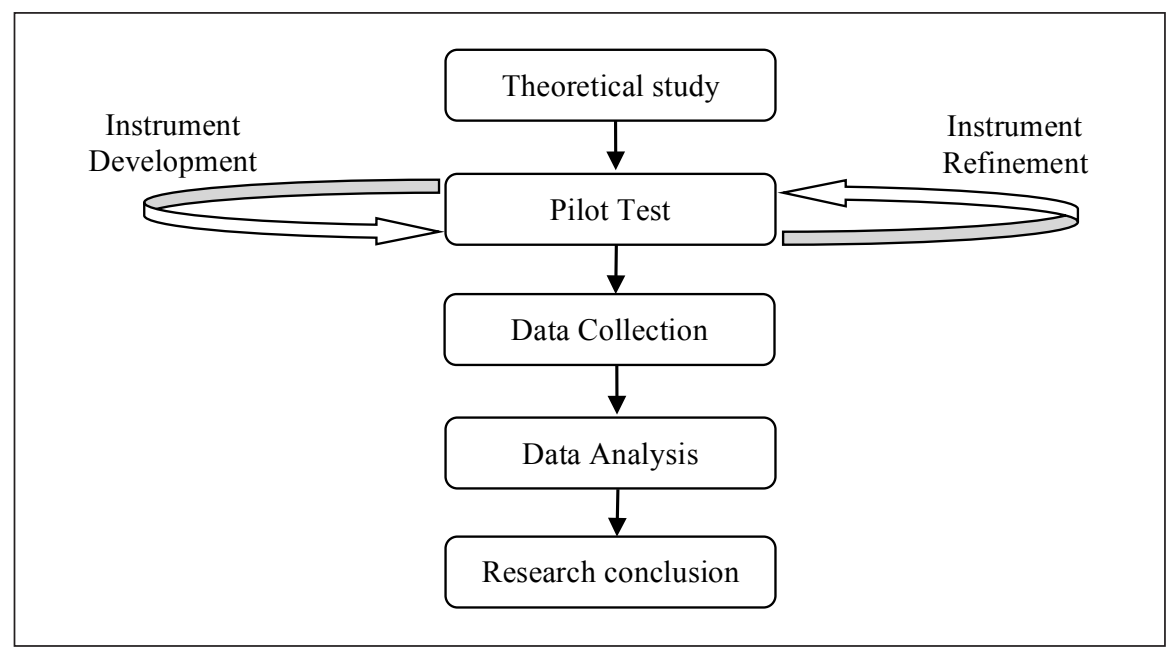

\subsection{Measure}

The constructs in structural model consist of English language proficiency (ELP), Academic Achievements (AA) and social capital outside family (SOF). The instrument is developed based on the structural model. It consists of marks that the students get in their English language course offered in the university (English for Communication II) and students' CGPA. Hair et al. (1995) stated that the minimum recommended number for each construct would be three, but Ho (2006) claimed that the minimum number for each construct is one, given that the item able to explain the construct. Johnson (1988) indicated that English result is sufficient to measure English language proficiency and CGPA can be used to measure academic achievement.

The mediating effect of social capitals is taken from Coleman (1988), who defined social capitals into outside family. The mediating effect will indicate that the effect of an independent variable towards established equation of independent and dependent variable (Baron \& Kenny, 1986). All items in the questionnaire were measured using a five point Likert scale ranged from "1-Strongly disagree", "2-Disagree”, "3-Don’t Know”, "4-Agree“, and "5-Strongly agree”. 
Figure 2: The effect of Social Capital outside Family towards Academic Achievement and the research hypotheses

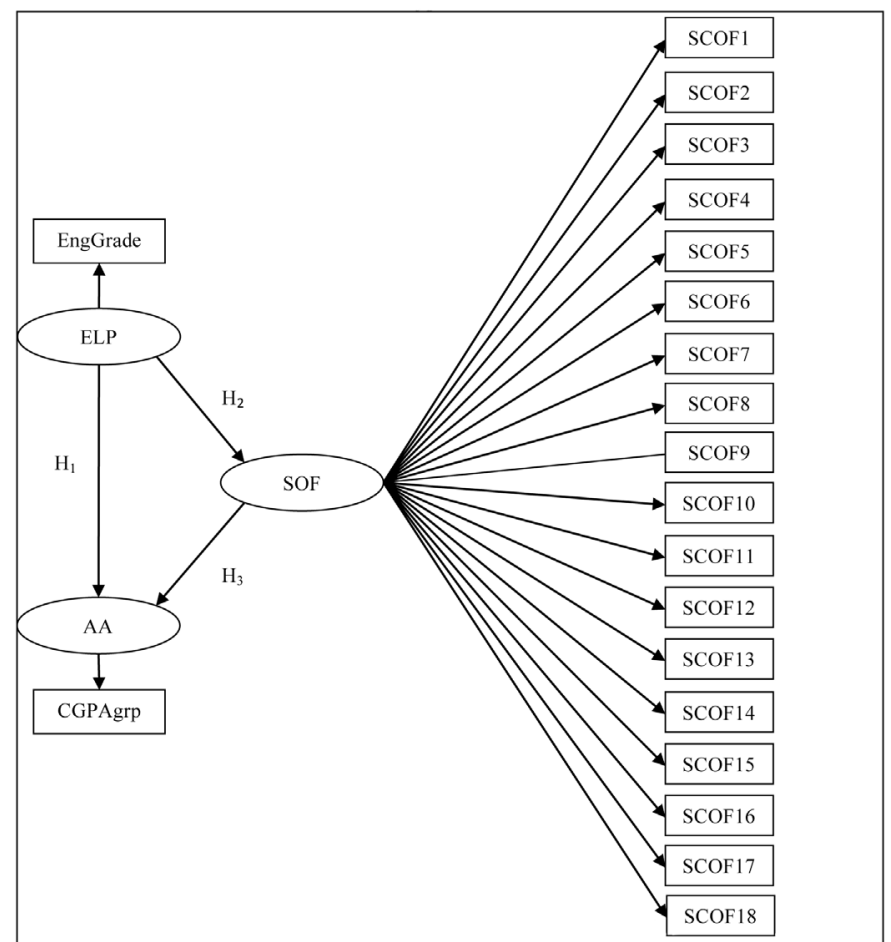

Note: SCOF1-SCOF18: Items for SCOF

For mediation effect of social capital, the findings are analysed based on Sobel's (1982) mediating procedure. Sobel's test provides an approximate significance test for the indirect effect of the independent variable on the dependent variable via the mediator (Baron \& Kenny, 1986).

\section{FINDINGS}

\subsection{Descriptive Analysis}

Table 1 depicts the demographic background of the respondents. There were altogether 81 respondents participated in this study where females dominates males respondents. The respondents are from the second and third year undergraduate economic students.

Table 1 summarizes the demographic profile of the respondents. In term of respondents, almost $76.50 \%$ were female and they came from various races although biggest majority was from Malaysian Chinese students. The data also shows that all of the respondents are currently in year 2 and 3. 
Table 1: Respondents' demographic background

\begin{tabular}{lcc}
\hline & Frequency & Percentage \\
\hline Gender & & \\
Male & 19 & 23.50 \\
Female & 62 & 76.50 \\
Citizenship & & \\
Malaysian & 80 & 98.80 \\
Non-Malaysian & 1 & 1.20 \\
Race & & \\
Malay & 28 & 34.60 \\
Chinese & 52 & 64.20 \\
Indian & 0 & 0.00 \\
Others & 1 & 1.20 \\
Current Semester & & \\
Semester 1 and 2 & 0 & 0.00 \\
Semester 3 and 4 & 64 & 79.00 \\
Semester 5 and 6 & 17 & 21.00 \\
Semester 7 and 8 & 0 & 0.00 \\
\hline
\end{tabular}

The students CGPA have been grouped according to the UUM degrees classification as in Table 2 and the demographic findings of respondents CGPA in Table 3.

Table 2: CGPA grouping

\begin{tabular}{ccc}
\hline Class & Criteria (CGPA) & Indicators \\
\hline First Class Honours & $3.67-4.00$ & 5 \\
Upper Second Class & $3.00-3.66$ & 4 \\
Lower Second Class & $2.00-2.99$ & 3 \\
Conditional Pass & $1.50-1.99$ & 2 \\
Fail & Below 1.50 & 1 \\
\hline
\end{tabular}

Table 3: Respondents demographic CGPA

\begin{tabular}{ccc}
\hline Class & Frequency & Percentage \\
\hline First Class Honours & 13 & 16.00 \\
Upper Second Class & 61 & 75.30 \\
Lower Second Class & 7 & 8.60 \\
Conditional Pass & 0 & 0.00 \\
Fail & 0 & 0.00 \\
Total & $\mathbf{8 1}$ & $\mathbf{1 0 0}$ \\
\hline
\end{tabular}


Since students need to provide their grade achieved for the English for Communication II, then the grades also have been classified into 5 categories as in Table 4 and the demographic finding for grades in Table 5 .

Table 4: Grades grouping

\begin{tabular}{cc}
\hline Grades & Indicators \\
\hline A, A- & 5 \\
B,+ B, B- & 4 \\
C,+ C & 3 \\
D & 2 \\
F & 1 \\
\hline
\end{tabular}

Table 5: The demographic for grades grouping

\begin{tabular}{ccc}
\hline Class indicators & Frequency & Percentage \\
\hline 5 & 35 & 43.20 \\
4 & 45 & 55.60 \\
3 & 1 & 1.20 \\
2 & 0 & 0.00 \\
1 & 0 & 0.00 \\
Total & $\mathbf{8 1}$ & $\mathbf{1 0 0}$ \\
\hline
\end{tabular}

\subsection{Goodness of measures analysis}

Validity and reliability test are done to ensure the goodness of fit. Sekaran and Bougie (2010) defined reliability as a test of how consistently a measuring instrument measures the concept it is measuring and validity as a test of how well an instrument that is developed measures the particular concept it is intended to measures.

\subsection{Construct validity}

Construct validity is important to demonstrate on how well the results obtained from the use of measure fit the theories around which the test is designed (Sekaran \& Bougie, 2010). So, it will help to clarify the questions on validity of the instrument to tap the concept as theorized, which can be done through convergent and discriminant validity.

The initial loading and cross loading is depicted in Table 6 and the final result of loading and cross loading for Model 2 in Table 7. Hair et al. (2010) stated that the cut-off value for loadings is at 0.5 as significant, but they could all be considered according to Asparouhov and Muthen (2009) and Friendly (2010) who outlined that the minimum factor loading should be 0.3 . Also, if any items which has a loading of more than 0.5 or 0.3 on two or more factors, then they will be considered as not having a significant cross loading. Table 7 indicates all the items measuring a particular construct loaded highly on that construct and loaded lower on the other constructs. Thus, confirming the construct validity for the Model. 
Table 6: Initial loading and cross loading

\begin{tabular}{cccc}
\hline & AA & ELP & SOF \\
\hline CGPAgrp & $\mathbf{1 . 0 0 0 0}$ & 0.4115 & 0.3326 \\
EngGrade & 0.4115 & $\mathbf{1 . 0 0 0 0}$ & 0.3233 \\
SCOF1 & -0.0077 & -0.0003 & 0.3617 \\
SCOF2 & -0.0277 & -0.0085 & 0.3450 \\
SCOF3 & 0.1687 & 0.1448 & $\mathbf{0 . 5 2 3 6}$ \\
SCOF4 & 0.1094 & 0.0997 & $\mathbf{0 . 4 6 5 5}$ \\
SCOF5 & 0.0948 & -0.0016 & $\mathbf{0 . 5 2 3 1}$ \\
SCOF6 & 0.0431 & -0.0136 & $\mathbf{0 . 4 3 9 4}$ \\
SCOF7 & -0.0721 & -0.0541 & 0.2583 \\
SCOF8 & 0.1113 & 0.0114 & $\mathbf{0 . 4 3 5 7}$ \\
SCOF9 & 0.0984 & 0.0268 & $\mathbf{0 . 4 5 0 5}$ \\
SCOF10 & -0.0152 & 0.1776 & 0.0580 \\
SCOF11 & 0.2110 & 0.1819 & $\mathbf{0 . 5 6 0 6}$ \\
SCOF12 & 0.3511 & 0.1425 & $\mathbf{0 . 6 6 6 5}$ \\
SCOF13 & 0.1718 & 0.1783 & $\mathbf{0 . 6 8 8 5}$ \\
SCOF14 & 0.1567 & 0.2365 & $\mathbf{0 . 5 9 0 3}$ \\
SCOF15 & 0.1791 & 0.2393 & $\mathbf{0 . 6 0 5 7}$ \\
SCOF16 & 0.1683 & 0.2500 & $\mathbf{0 . 7 1 6 8}$ \\
SCOF17 & 0.2620 & 0.3171 & $\mathbf{0 . 7 4 9 6}$ \\
SCOF18 & -0.1455 & -0.051 & -0.366 \\
\hline
\end{tabular}

Table 7: Loading and cross loading

\begin{tabular}{cccc}
\hline & AA & ELP & SOF \\
\hline CGPAgrp & $\mathbf{1 . 0 0 0 0}$ & 0.4115 & 0.3209 \\
EngGrade & 0.4115 & $\mathbf{1 . 0 0 0 0}$ & 0.3075 \\
SCOF3 & 0.1687 & 0.1448 & $\mathbf{0 . 5 4 2 1}$ \\
SCOF4 & 0.1094 & 0.0997 & $\mathbf{0 . 4 9 8 6}$ \\
SCOF5 & 0.0948 & -0.0016 & $\mathbf{0 . 5 2 4 8}$ \\
SCOF6 & 0.0431 & -0.0136 & $\mathbf{0 . 4 4 6 6}$ \\
SCOF8 & 0.1113 & 0.0114 & $\mathbf{0 . 4 4 8 1}$ \\
SCOF9 & 0.0984 & 0.0268 & $\mathbf{0 . 4 6 2 7}$ \\
SCOF11 & 0.211 & 0.1819 & $\mathbf{0 . 5 6 1 1}$ \\
SCOF12 & 0.3511 & 0.1425 & $\mathbf{0 . 6 6 6 1}$ \\
SCOF13 & 0.1718 & 0.1783 & $\mathbf{0 . 6 8 8 6}$ \\
SCOF14 & 0.1567 & 0.2365 & $\mathbf{0 . 5 8 0 4}$ \\
SCOF15 & 0.1791 & 0.2393 & $\mathbf{0 . 6 0 2 6}$ \\
SCOF16 & 0.1683 & 0.25 & $\mathbf{0 . 7 0 7 9}$ \\
SCOF17 & 0.262 & 0.3171 & $\mathbf{0 . 7 5 4 9}$ \\
\hline
\end{tabular}




\subsection{Convergent validity}

Convergent validity is conducted which is to test the degree to which multiple items to measure the same concept are in agreement. Hair et al. (2010) suggested using factor loadings, composite reliability (CR) and average variance extracted (AVE) to access convergence validity. Table 8 depicts the convergent validity for the model. The AVE measures the variance captured by the indicators relative to measurement error. Barclay et al. (1995) and Fornell and Larcker (1981) stated that AVE should be greater than 0.5 to justify using the construct. In this model, the values for AVE for each constructs are above 0.5 and ranged from 0.7348 to 1 .

Table 8 depicts the values for AVE for each constructs are above 0.5 and ranged from 0.5412 to 1 . The results showed that all the constructs are all valid measures based on their parameter estimates and statistical significant.

Table 8: Result for measurement model

\begin{tabular}{lcccr}
\hline \multicolumn{1}{c}{ Model construct } & $\begin{array}{c}\text { Measurement } \\
\text { item }\end{array}$ & Loading & CR & AVE \\
\hline English Language Proficiency & EngGrade & 1.0000 & 1.0000 & 1.0000 \\
Students' CGPA & CGPAgrp & 1.0000 & 1.0000 & 1.0000 \\
Social Capital Outside Family & SCOF3 & 0.5421 & 0.8450 & 0.5412 \\
& SCOF4 & 0.4986 & & \\
& SCOF5 & 0.5248 & & \\
& SCOF6 & 0.4466 & & \\
SCOF8 & 0.4481 & & \\
& SCOF9 & 0.4627 & & \\
& SCOF11 & 0.5611 & & \\
SCOF12 & 0.6661 & & \\
& SCOF13 & 0.6886 & & \\
SCOF14 & 0.5804 & & \\
SCOF15 & 0.6026 & & \\
& SCOF16 & 0.7079 & & \\
SCOF17 & 0.7549 & & \\
\hline
\end{tabular}

Table 9 summarizes the results of the measurement model. The results showed that all the constructs are all valid measures based on their parameter estimates and statistical significant (Chow \& Chan, 2008).

Table 9: Summary results of the Model construct

\begin{tabular}{lccc}
\hline \multicolumn{1}{c}{ Model construct } & $\begin{array}{c}\text { Measurement } \\
\text { item }\end{array}$ & $\begin{array}{c}\text { Standardized } \\
\text { estimate }\end{array}$ & T-value \\
\hline English Language Proficiency & EngGrade & 1.0000 & 0 \\
Students' CGPA & CGPAgrp & 1.0000 & 0 \\
Social Capital Within Family & SCOF3 & 0.5421 & 4.386 \\
\hline
\end{tabular}


Table 9: Summary results of the Model construct (cont)

\begin{tabular}{|c|c|c|c|}
\hline Model construct & $\begin{array}{c}\text { Measurement } \\
\text { item }\end{array}$ & $\begin{array}{c}\text { Standardized } \\
\text { estimate }\end{array}$ & T-value \\
\hline & SCOF4 & 0.4986 & 3.030 \\
\hline & SCOF5 & 0.5248 & 3.196 \\
\hline & SCOF6 & 0.4466 & 3.368 \\
\hline & SCOF8 & 0.4481 & 2.277 \\
\hline & SCOF9 & 0.4627 & 2.780 \\
\hline & SCOF11 & 0.5611 & 4.174 \\
\hline & SCOF12 & 0.6661 & 4.862 \\
\hline & SCOF13 & 0.6886 & 4.685 \\
\hline & SCOF14 & 0.5804 & 4.17 \\
\hline & SCOF15 & 0.6026 & 4.804 \\
\hline & SCOF16 & 0.7079 & 6.705 \\
\hline & SCOF17 & 0.7549 & 9.309 \\
\hline
\end{tabular}

\subsection{Discriminant validity}

The discriminant validity of the measures is the degree to which items differentiates among constructs or measures distinct concepts (Ramayah, Lee \& In, 2011). It was access or validated based on the square root of the AVE value of a construct and should be greater than the correlations between the constructs (Fornell \& Larcker, 1981). Table 10 shows the square root correlations for each construct and are less than the average variance extracted by the indicators measuring the construct indicating adequate discriminant validity, with exception given to the first two constructs that only measures one item.

Table 10: Summary results of the Model construct

\begin{tabular}{lccc}
\hline \multicolumn{1}{c}{ Constructs } & AA & ELP & SWF \\
\hline Academic Achievement (AA) & $\mathbf{1 . 0 0 0 0}$ & & \\
English Language Proficiency (ELP) & 0.4115 & $\mathbf{1 . 0 0 0 0}$ & \\
Social capital outside family (SOF) & 0.3209 & 0.3075 & $\mathbf{0 . 7 3 5 7}$ \\
\hline
\end{tabular}

\subsection{Reliability analysis}

To assess the inter item consistency of the measurement items for the model; Cronbach's alpha coefficient is used. Table 11 summarizes the loadings and alpha values.

All Cronbach's alpha values are above 0.6 as suggested by Nunnally (1978). The composite reliability values are ranged from 0.8450 to 1.0000 . Interpreted like a Cronbach's alpha for internal consistency reliability estimate, a composite reliability of 0.70 or greater is considered acceptable (Fornell \& Larcker, 1981). Therefore, it can be concluded that the measurements are reliable. 
Table 11: Result of reliability test

\begin{tabular}{lcccc}
\hline \multicolumn{1}{c}{ Constructs } & $\begin{array}{c}\text { Measurement } \\
\text { items }\end{array}$ & $\begin{array}{c}\text { Cronbach's } \\
\text { alpha }\end{array}$ & $\begin{array}{c}\text { Loading } \\
\text { Range }\end{array}$ & $\begin{array}{c}\text { Number } \\
\text { of items }\end{array}$ \\
\hline English Language Proficiency (ELP) & $\begin{array}{c}\text { EngGrade } \\
\text { CGPAgrp }\end{array}$ & 1 & & \\
Academic Achievement (AA) & SCOF3, SCOF4, & & & \\
Social Capital OutsideFamily (SOF) & $\begin{array}{l}\text { SCOF, SCOF6, } \\
\text { SCOF5, }\end{array}$ & & \\
& SCOF8, SCOF9, & & \\
& SCOF11, SCOF12, 0.845 & $0.4466-0.7549$ & $13(18)$ \\
& SCOF13, SCOF14, & & & \\
& SCOF15, SCOF16, \\
& SCOF17 & & & \\
& & & & \\
&
\end{tabular}

\subsection{Structural Model and Hypothesis Testing}

Figure 3 and Table 12 show the result of the structural model. From the analysis, the direct effect of ELP towards AA is greater $(\beta=0.345, t=3.429, \mathrm{p}<0.01)$ compared to the effect of SOF towards AA $(\beta=0.215, \mathrm{t}=2.132, \mathrm{p}<0.01)$. Also, SOF shows that ELP was positively

Figure 3: Result for the path analysis

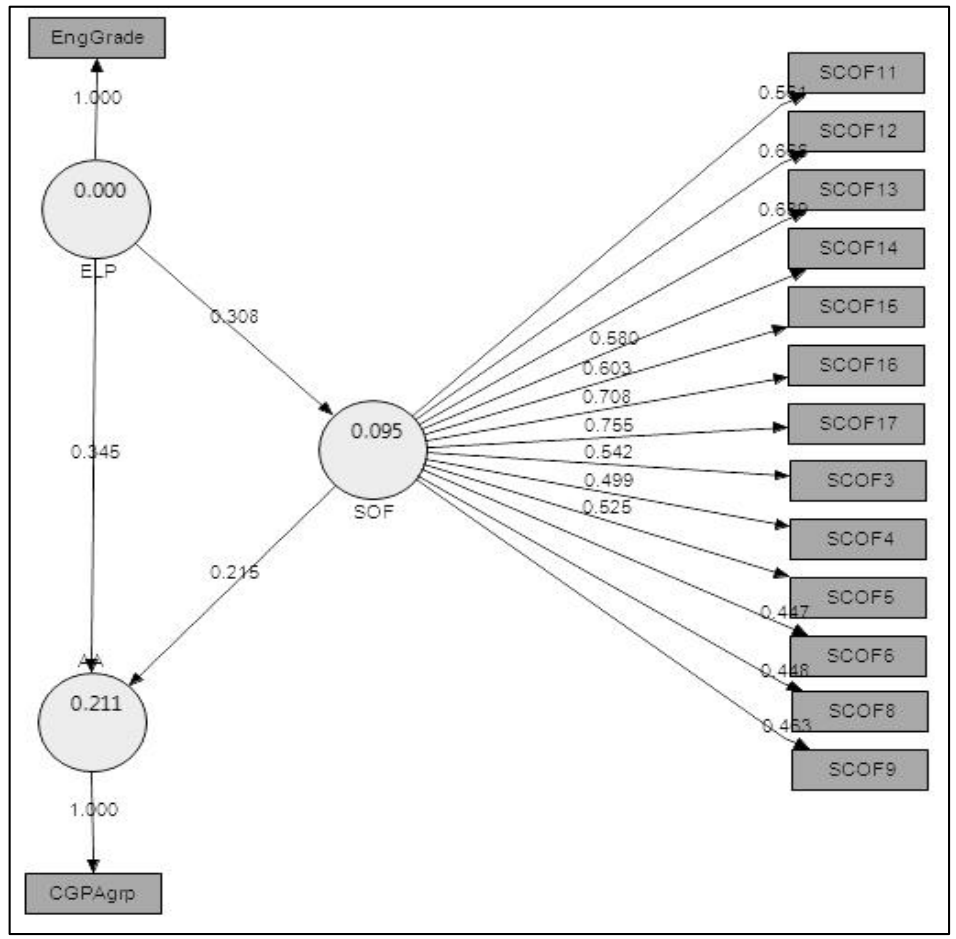


related to SOF $(\beta=0.308, \mathrm{t}=2.774, \mathrm{p}<0.01)$. The $\mathrm{R}^{2}$ value for AA was 0.211 suggesting that $21.1 \%$ of the variance can be explained by ELP and SOF. Thus, $\mathrm{H}_{1}, \mathrm{H}_{2}$ and $\mathrm{H}_{3}$ were supported.

Table 12: Path Coefficient and hypothesis testing for Model 2

\begin{tabular}{ccccc}
\hline Hypothesis & Relationship & Coefficient & $\boldsymbol{t}$ value & Supported \\
\hline $\mathrm{H}_{1}$ & $\mathrm{ELP} \rightarrow$ AA & 0.345 & 3.429 & YES \\
$\mathrm{H}_{2}$ & $\mathrm{ELP} \rightarrow \mathrm{SOF}$ & 0.308 & 2.774 & YES \\
$\mathrm{H}_{3}$ & $\mathrm{SOF} \rightarrow \mathrm{AA}$ & 0.215 & 2.132 & YES \\
\hline
\end{tabular}

\subsection{Mediating effect}

To the for the mediation effect, a mediating analysis procedure as described by Baron and Kenny (1986) was used. The significance of the mediating process was based on Sobel's test value (z-value). If the z-value exceeded 1.96, it shows that there is a significant mediating relationship $(\mathrm{p}<0.05)$. The $\mathrm{z}$-value is formally defined as

$$
z=\frac{a \times b}{\sqrt{b^{2} \times s_{a}^{2}+a^{2} \times s_{b}^{2}+s_{a}^{2} \times s_{b}^{2}}}
$$

However, for simplicity, a freely available calculator is used from http://www.danielsoper. $\mathrm{com} /$ statcalc $3 /$ calc.aspx $\mathrm{id}=31$.

There is a significant impact of ELP on SFF $(\beta=0.308, \mathrm{p}<0.01)$ as well as SOF to AA ( $\beta$ $=0.215, p<0.01)$. Since there is also a significant, direct impact of ELP on AA $(\beta=0.345$, $\mathrm{p}<0.01)$, SOF is established as partial mediator. The mediating is confirmed by z-statistic (Sobel, 1982) where $z$-value $=2.116$. So $\mathrm{H}_{4}$ was supported.

\section{CONCLUSION}

Research findings reveal that there is a significant direct impact of ELP towards AA. It also indicates a significant direct impact of SOF $(\mathrm{ELP} \rightarrow \mathrm{SOF})$ and towards $\mathrm{AA}(\mathrm{SOF} \rightarrow \mathrm{AA})$. Sobel's test of mediating procedure indicates mediating effect SOF (ELP $\rightarrow$ SOF $\rightarrow$ AA) is significant.

This study contributed for better understanding of important ELP and SOF towards student's performance. However the domain has been limited towards undergraduate economics students studying in UUM, who currently undergoing second to fourth year and completed their English for communication II subject. The English language proficiency only being measured through students' result in English for Communication II and academic performance was measured 
using students' current CGPA. Also, the items for social capital are group generally within a construct and not being classified according to their characteristics.

The objective of GTP is producing highly knowledgeable students equitable with international standard. It is one of the elements in becoming a high income nation (GTP, 2011). Therefore, strengthening students' ELP helps to elevate students to a higher standard, internationally.

This study can be developed further by including more constructs to measure English language proficiency and academic achievements. Items for social capital outside family can also be classified accordingly as to Coleman (1988) and analysis can be made to examine the effect that each construct would have towards social capital.

\section{REFERENCES}

Adler, P. S., \& Kwon, S. (2002). Social Capital: Prospect for a New Concept. Academy of Management Review, 27(1), 17 - 40.

Asparouhov, T., \& Muthen, B. (2009). Exploratory structural equation modeling. Los Angeles: Psychology Press.

Bachman, L. F. (1990). Fundamental considerations in languages testing. Oxford: Oxford University Press.

Barclay, D. W., Thompson, R., \& Higgins, C. (1995). The partial least squares (PLS) approach to causal modelling: personal computer adoption and use an illustration. Technology Studies, 2(2), 285-309.

Baron, R. M., \& Kenny, D. A. (1986). The Moderator-Mediator Variable Distinction in Social Psychological Research: Conceptual, Strategic and Statistical Consideration. Journal of Personality and Social Psychology, 51(6), 1173 - 1182.

Bourdieu, P. (1986). The Form of Capital. In J. Richardson (Eds.), Handbook of Theory and Research for the Sociology of Education. (pp. 241 - 258). Westport, CT: Green-wood Press.

Chin, W.W. (1998). Issues and Opinion on Structural Equation Modelling. MIS Quarterly, 22(1), $7-16$.

Chow, W. S., \& Chan, L. S. (2008). Social Network and Shared Goals in Organizational Knowledge Sharing. Information and Management, 45(7), 458 - 465.

Coleman, J. (1988). Social Capital in the Creation of Human Capital. American Journal of Sociology, 94 (Issue supplement), S95-S120. 
Croll, P. (2004). Families, Social Capital and Educational Outcome. British Journal of Educational Studies, 52(4), $390-416$.

Crosnoe, R. (2004). Social Capital and the Interplay of Families and School. Journal of Marriage and Family, 66(2), 267-280.

Dika, S. L., \& Singh, K. (2002). Application of Social Capital in Educational Literature: A Critical Synthesis. Review of Educational Research, 72(1), 31 - 60.

Drennan, L. G., \& Rohde, F. H. (2002). Determinants of Performance in Advance Undergraduate Management Accounting: An Empirical Investigation. Accounting and Finance, 42(1), $27-40$.

Fornell, C., \& Larcker, D. F. (1981). Evaluating Structural Equation Models with Unobservable Variables and Measurement Error. Journal of Marketing Research, 18(1), 39-50.

Friendly, M. (2010). Planning a Factor Analytic study. Retrieved February 10, 2012, from http://www.psych.yorku.ca/lab/psy6140/fa/facplan.htm.

Government Transformation Program. (2011), Laporan Pelan Hala Tuju GTP 2.0, Bab 2. Retrieved February 11, 2012, from http://www.pemandu.gov.my/gtp/resources_reports. aspx?lang=ms-my

Hair, J. F., Anderson, R. E., Tatham, R. L., \& Black, W. C. (1995), Multivariate Data Analysis with Readings, 4th ed. Englewood Cliffs, NJ: Prentice-Hall.

Hair, J. F., Black, W. C., Babin, B. J., \& Anderson, R. E. (2010). Multivariate Data Analysis. Upper Saddle River: Prentice-Hall

Hj Sarudin, I., Zubairi, A. M., Nordi, M. S., \& Omar, M. A. (2008).The English Language Proficiency of Malaysian Public University Students. In Ministry of Higher Education, Malaysia (Eds.), Enhancing the Quality of Higher Education through Research: Shaping Future Police, (pp40 - 65). Putrajaya: Ministry of Higher Education.

Ho, R. (2006). Handbook of univariate and multivariate data analysis and interpretation with SPSS. Boca Raton: Chapman and Hall/CRC

Jalaluddin, N. H., Mat Awal, N., \& Abu Bakar, K. (2009). Linguistic and Environment in English Language Learning: Towards the Development of Quality Human Capital. European Journal of Social Science, 9(4), 627 - 642.

Johnson, P. (1988), English Language Proficiency and Academic Performance of Undergraduate International Students. Teachers of English to Speaker of Other Languages, Inc. (TESOL), TESOL Quarterly, 22(1), $164-168$. 
Kwok, M. (2004). Disciplinary differences in the development of employability skills of recent university, graduates in Manitoba: Some initial findings. Higher Education Perspectives, 1,1 .

Naderi, H., Abdullah, R., Aizan, H. T., Sharir, J., \& Kumar, V. (2009). Self Esteem, Gender and Academic Achievement of Undergraduate Students. American Journal of Scientific Research, 3, $26-37$.

Nunnally, J. C. (1978). Psychometric theory. NY: McGraw-Hill

Oller, J. W. (1983). Issues in language testing research (Eds.). Rowley, MA: Newbury House Publishers.

Putnam, R. (2001). Social Capital: Measurement and Consequences. Isuma: Canadian Journal of Policy Research, 2, 41-51.

Ramayah, T., Lee, J.W.C. \& In, J.B.C. (2011). Network Collaboration and Performance in the Tourism Sector. Service Business, 5(4), 411 - 428.

Sekaran, U., \& Bougie, R. (2010). Research Methods for Business: A skill Building approach. UK: Wiley.

Sobel, M. E. (1982). Asymptotic confidence intervals for indirect effects in structural equation models. In S. Leinhardt (Eds.), Sociological Methodology 1982 (pp. 290-312). Washington, DC: American Sociological Association.

Stephen, D. F., Welman, J. C., \& Jordaan, W. J. (2004). English Language Proficiency as an Indicator of Academic Performance at a Tertiary Institution. SA Journal of Human Resource Management, 2(3), 42 - 53.

Thang, S. M., \& Ting, S. L., \& Jaafar, N. M. (2011). Attitudes and Motivation of Malaysian Secondary Students towards learning English as a Second Language: A Case Study. The Southeast Asian Journal of English Language Studies, 17(1), 40-54.

UUM (2012). Sistem Maklumat Pelajar 2012.

Yasin, A. Y. M., Shaupil, W. M. H. W. M., Muhktar, A. M., Ghani, N. I. A., \&, Rashid, F. (2010). The English Language Proficiency of Civil Engineering Students at a Malaysian Polytechnic. Asian Social Science, 6(6), 161 - 170. 